\title{
Covid-19 Sürecinde Hemşirelik Öğrencilerinin Uzaktan Eğitime Yönelik Görüşleri ve Kaygı Düzeyleri
}

\author{
Hanife DURGUN* Tayfur CAN** Ayşe Betül AVCI** Betül KALYONCUOĞLU**
}

Öz

Giriş: Covid -19 pandemisiyle birlikte tüm eğitim düzeylerinde eğitimin devamlılığının sağlanabilmesi amacıyla uzaktan eğitim yaygın şekilde kullanılmaya başlanmıştır. Amaç: Araştırma, Covid-19 pandemi sürecinde hemşirelik öğrencilerinin uzaktan eğitime yönelik görüşleri ile kaygı düzeyleri arasındaki ilişkinin belirlenmesi amacıyla yapılmıştır. Yöntem: Tanımlayıcı ve ilişki arayıcı türde gerçekleştirilmiş olan araştırma Mayıs-Haziran 2020 tarihleri arasında gerçekleştirildi. Araştırmanın evrenini 2019-2020 eğitim öğretim yılı içerisinde Türkiye'de hemşirelik bölümünde lisans öğrenimi görmekte toplam 85.162 öğrenci, örneklemi ise; evrende eleman sayısı bilinen formüle göre hesaplanan toplam 810 hemşirelik öğrencisi oluşturdu. Veri toplama, Kişisel Bilgi Formu, Uzaktan Eğitime Yönelik Görüşler Ölçeği ve Durumluluk Süreklilik Kaygı Envanteri kullanılarak gerçekleştirildi. Araştırmadan elde edilen verilerin değerlendirilmesinde, sayı, yüzde, ortalama ve t testi, Mann Whitney U testi, Kruskal Wallis Testi ve Oneway Anova kullandı. Bulgular: Hemşirelik öğrencilerinin, uzaktan eğitime yönelik görüşler ölçeği puan ortalamasının $46.35 \pm 9.13$, Durumluluk Kaygı Envanteri puan ortalamasının $47.66 \pm 11.91$, Süreklilik Kaygı Envanteri puan ortalamasının $46.39 \pm 8.42$, Uzaktan Eğitime Yönelik Görüşler Ölçeği ile Durumluluk Kaygı puanları arasında negatif yönde istatistiksel olarak anlamlı bir ilişki $(r=-.22, p=.001)$, Süreklilik Kaygı puanları arasında negatif yönde bir ilişki olduğu fakat bu ilişkinin istatistiksel olarak anlamlı bir ilişki olmadığı $(r=-.02, p=.524)$, uzaktan eğitime yönelik görüşler ölçeği ile sınıf durumu arasında, durumluluk ve süreklilik kaygı envanteri ile gelir düzeyleri arasında istatistiksel olarak anlamlı ilişki olduğu saptandı. Sonuç: Öğrencilerin, uzaktan eğitime yönelik görüşleri, durumluluk ve süreklilik kaygı düzeyleri orta düzeydedir. Öğrenciler uzaktan eğitime yönelik olumlu görüşe sahip oldukça kayg1 düzeyleri azalmaktadır. Bu sonuçlar doğrultusunda, öğrencilerin uzaktan eğitime yönelik olumlu tutumlarının devam ettirilebilmesi ve kaygı düzeylerinin alt seviyede tutulabilmesi için otoriterelerin önerdiği çözüm önerilerinin göz önünde bulundurulması ve uygulamalı derslerin uygulama kısımlarının telafi eğitimleriyle tamamlanması önerilebilir.

Anahtar Sözcükler: Anksiyete, Covid-19, Hemşirelik, Uzaktan Eğitim.

\section{Abstract \\ Nursing Students' Views on Distance Education and Anxiety Levels in Covid-19 Process}

Background: In the Covid -19 pandemic during, distance education methods have been widely used in order to ensure the continuity of education at all educational levels. Objectives: The aim of this study was to investigate the relationship between nursing students' views on distance education and anxiety levels during the Covid-19 pandemic process. Methods: This descriptive and correlational type study was conducted between May and June 2020. The population of the research consisted of 80.000 students who are studying in the nursing department in Turkey. The sample was composed of 810 nursing students who were known formula. As a data collection tool; Personal Information Form, Perception Scale for Distance Education, State-Trait Anxiety Inventory were used. The data obtained; were analyzed using number, percentage, mean and t test, Mann Whitney U test, Kruskal Wallis Test and Oneway Anova. Results: The mean score of the students' Perception Scale for Distance Education, was $46.35 \pm 9.13$, the mean score of State Anxiety Inventory was $47.66 \pm 11.91$ and the mean score of Trait Anxiety Inventory was $46.39 \pm 8.42$. There was a statistically significant negative correlation between Perception Scale for Distance Education and State Anxiety Inventory scores $(r=-.22, p=.001)$, there was not a statistically significant between Perception Scale for Distance Education and Trait Anxiety Inventory scores $(r=-.02, p=.524)$. There was a statistically significant was found between the Perception Scale for Distance Education and class status, between the State and Trait Anxiety Inventory and income levels.

Conclusion: It is observed that the students' perception scale for distance education and status and trait anxiety levels are moderate. The anxiety levels decrease as the students have a positive view towards distance education. In line with these results, it may be suggested to consider the solution suggestions suggested by the authoritarians and to complete the practical parts of the applied courses with remedial training in order to maintain the positive attitudes of students towards distance education and to keep their anxiety levels at a low level.

Key Words: Anxiety, Covid-19, Nursing, Distance Education.

\section{Geliş tarihi: 11.11.2020 Kabul tarihi: 02.04.2021}

$\mathrm{T}$ üm dünyada ve ülkemizde yaşanmakta olan Covid-19 pandemisi, eğitim öğretimde aksamalara neden olmuş ve ülkemizde de eğitim öğretimde aksama yaşanmaması amacıyla, farklı eğitim yaklaşımları kullanılarak eğitim sisteminde yeniden yapılandırma zorunlu hale getirilmiştir. Bu kapsamda, eğitim yaklaşımlarından biri olan, bilgisayar ve bilişim teknolojisiyle de yaygın olarak birçok alanda kullanılmaya başlanan uzaktan eğitime geçilmiştir. Geleneksel eğitim-öğretimin çeşitli nedenlerden dolayı sınıf ortamında yapılamadığı durumlarda, eğitimciler ile öğrenciler arasındaki, haberleşmenin ve etkileşimin belli bir merkez üzerinden sağlandığı, çevirimiçi öğretim yöntemlerini kapsayan, bilgisayar tabanlı öğretim yöntemi olarak tanımlanan uzaktan eğitim (1-3), Amerika Birleşik Devletleri Uzaktan Eğitim Derneği (United States Distance Learning Association -USDLA) tarafından da "uydu, ses, video, bilgisayar, grafik, çoklu ortam teknolojisi gibi araçlar aracıllğıyla uzaktaki öğrencilerle eğitimin gerçekleştirilebilmesi" olarak tanımlanmaktadır (4).

Uzaktan eğitim ile var olan bilgisayar ağlarından yararlanılarak, eğitimci ile öğrenci arasında ders etkileşiminin sağlanabildiği, birbiri ile aynı ya da birbirinden farklı ortamdaki bireylerin kullanmış oldukları bilgisayar ağı ile birbirleri ile bilgi ve belgeleri paylaşabildiği, word dosyası, grafik, ders sunusu, ses, video gibi çoklu ortam uygulamaları ile desteklenmiş olan öğrenme ortamı sağlanabilmektedir $(5,6)$.

* Dr.Öğr.Üyesi, Ordu Üniversitesi Sağlık Bilimleri Fakültesi Hemşirelik Bölümü Hemşirelik Esasları AD. E-mail: hanife.balik@gmail.com ORCID ID: 0000-0003-1622-8184 ** Hemşirelik 3. Sınıf öğrencisi, Ordu Üniversitesi Sağlık Bilimleri Fakültesi Hemşirelik Bölümü, sırasıyla ORCID ID: 0000-0003-1985-5183, ORCID ID: 0000-0002-0000-9019, ORCID ID: 0000-0002-0362-552X 
Araştırma

Hemşirelik eğitimi açısından çok da yeni olmayan bu yöntem 1969 yılından bu yana konuşuluyor olmasına rağmen hemşirelikte ilk olarak Amerika Birleşik Devletleri’nin 1995 yılında uzaktan hemşirelik eğitim kursu vermesiyle başlamıştır (7). Ülkemizde de ilk olarak 1993 yılında açık öğretim fakültesi ile hemşirelikte ön lisans programı bünyesinde kullanılmıştır. Sağlık bakım hizmetlerinde yaşanan sürekli değişim ve gelişimle birlikte, hemşirelik bölümünden mezun olan öğrencilerin çok hızlı bir şekilde bu değişim ve gelişime uyum sağlaması beklenmektedir. Bu kapsamda uzaktan eğitim aracılığıyla, hemşireler mezun olduktan sonra mesleki kurslara, sertifika programlarına, lisans tamamlama programlarına, lisans ve lisansüstü eğitim programlarına katılarak yaşam boyu öğrenmeyi sürdürebilmektedirler (8). Hem ülkemizde hem de tüm dünya genelinde giderek artmakta olan hemşire talebini karşılayabilmek adına açılan hemşirelik okullarına olan talebin artması nedeniyle, artan ve artmakta olan öğrenci kontejanları için olması gereken sayıdaki öğretim elemanı kadrolarında yaşanmakta olan sıkıntılarla birlikte, beraberinde okulların fiziki koşullarının uygun olmaması nedeniyle eğitim programlarında düzenlemelere gidilmiş ve geleneksel eğitim yöntemleri ile uzaktan eğitim modelleri entegre edilerek sorunlara çözüm bulunmaya çalışılmıştır.

Tüm dünyada olduğu gibi ülkemizde de Mart 2020 tarihinden itibaren Covid-19 pandemisi nedeniyle eğitim süreci etkilenmiş ve sosyal mesafenin sağlanabilmesi aynı zamanda eğitimlerin devam ettirilebilmesi amacıyla YÖK' nun kararı ile üniversitelerde yüz yüze eğitim sonlandırılmış ve uzaktan eğitime geçiş için 6 Mart 2020 tarihinde uzaktan öğretimin uygulanabilmesi için gerekli yol haritası belirlenmiştir (9). Fakat hemşirelik mesleği gibi bilişsel, duyuşsal ve psikomotor becerileri içeren uygulamalı eğitim programlarında temel hemşirelik becerilerinin geleneksel eğitim yöntemleri kullanılarak kazandırılması oldukça önemlidir Bu süreçte öğrencilerin temel becerileri laboratuvar ortamında gerçekleştiremeyecek olması, uygulama alanlarından uzak olmaları, uzaktan eğitimle gerçekleştirilen derslere ve sınavlara yönelik tecrübesiz olmaları, teknolojik olarak mağduriyet yaşayabilme durumları gibi nedenlerden dolayı uzaktan eğitime ilişkin kaygı yaşayabilecekleri düşünülmektedir.

\title{
Araştırmanın Amacı
}

$\mathrm{Bu}$ araştırma, ülkemizin de içinde bulunduğu Covid-19 pandemi sürecinde hemşirelik öğrencilerinin uzaktan eğitime yönelik görüşleri ile kaygı düzeyleri arasındaki ilişkinin belirlenmesi amacıyla yapılmıştır.

\section{Araştırma Soruları}

1) Hemşirelik öğrencilerinin uzaktan eğitime yönelik görüşleri nelerdir?

2) Hemşirelik öğrencilerinin kaygı düzeyleri nasıldır?

3) Hemşirelik öğrencilerinin uzaktan eğitime yönelik görüşleri ile kaygı düzeyleri arasında ilişki var mıdır?

4) Hemşirelik öğrencilerin sosyo - demografik özelliklerine göre uzaktan eğitime yönelik görüşleri ile durumluluk ve süreklilik kaygı düzeyleri arasında farklılık var mıdır?

\section{Yöntem}

\section{Araştırmanın Tipi}

Araştırma tanımlayıcı-ilişki arayıcı tipte bir araştırmadır.

\section{Araştırmanın Yapıldı̆̆ Yer}

Araştırma, Mayıs - Haziran 2020 tarihleri arasında Türkiye genelinde hemşirelik bölümünde öğrenim gören hemşirelik öğrencileri ile yürütülmüştür.

\begin{abstract}
Araştırmanın Evreni/Örneklemi
Araştırmanın evrenini, 2019-2020 eğitim öğretim yılı içerisinde Türkiye'de hemşirelik bölümünde lisans öğrenimi görmekte olan toplam 85.162 öğrenci oluşturmuştur (10). Araştırmanın örneklemi için ise; evrende eleman sayısı bilinen formül ile \% 5 kabul edilebilir hata, \%99 güven aralığına göre hesaplanarak gerekli örneklem büyüklüğünün 659 kişi olduğu saptanmıştır. Ancak herhangi bir veri kaybı riski göz önünde bulundurularak belirlenen örneklem sayısının \%20 fazlası alınarak gerekli örneklem sayıs1 810 olarak belirlenmiştir. Örneklemin belirlenmesinde, amaçlı örnekleme yöntemlerinden kartopu örnekleme yöntemi kullanılmış, online olarak hazırlanmış veri toplama formları ilk olarak araştırmaya katılmayı kabul eden üniversite öğrencilerine dağıtılmış ve öğrencilerden veri toplama formlarını hemşirelik bölümünde öğrenim gören başka arkadaşlarına iletmeleri konusunda destek alınmıştır. Araştırma Türkiye'de ikamet eden, hemşirelik bölümünde öğrenim gören, 18 yaşında veya daha büyük olan ve araştırmaya katılmayı kabul eden 810 hemşirelik öğrencisi ile gerçekleştirilmiştir.
\end{abstract}

\section{Veri Toplama Araçları}

Araştırmada veri toplama aracı olarak araştırmacılar tarafından literatür doğrultusunda geliştirilen Kişisel Bilgi Formu, Uzaktan Eğitime Yönelik Görüşler Ölçeği (UEYGÖ) ve Durumluk ve Sürekli Kaygı Envanteri (DKE-SKE) kullanılmıştır.

\section{Kişisel Bilgi Formu}

$\mathrm{Bu}$ form, literatürdeki benzer araştırmalar incelenerek hazırlanmıştır $(2,3,6,8)$. Formda bireylerin sosyodemografik özelliklerine ve eğitim durumlarına ilişkin toplam 12 soru yer almaktadır.

\section{Uzaktan Eğitime Yönelik Görüşler Ölçeği (UEYGÖ)}

Yıldırım ve ark.(11) tarafından 2014 yılında Türkiye'de geliştirilmiş ve aynı zamanda geçerlik ve güvenirliği yapılmış olan ölçek, öğrencilerin uzaktan eğitime yönelik görüşlerini belirleyebilmek amaciyla geliştirilmiştir. Ölçek 18 madde ve "Kişisel uygunluk", "Etkililik", “Öğreticilik” ve "Yatkınlık” olmaz üzere dört alt boyuttan oluşan beşli likert tipindedir. Ölçekten minimum alınabilecek 18, maksimum alınabilecek puan ise 90'dır. Ölçekten alınan puan arttıkça bireylerin uzaktan eğitime 
Araştırma

yönelik olumlu görüş bildirdikleri kabul edilmektedir. Ölçeğin toplam Cronbach alfa değeri, Yıldırım ve ark. (11) yapmış oldukları araştırmada .86 olarak, bu araştırmada ise, .75 olarak bulunmuştur.

\section{Durumluluk-Süreklilik Kaygl Envanteri (DKE-SKE)}

Spielberger ve ark. tarafından 1970 yılında geliştirilmiş olan ölçek, Öner ve Le Compte tarafından 1975 yılında Türkçe güvenirliği, Öner tarafından da 1977 yılında geçerliği yapılmıştır (12,13). Bireylerin kaygı düzeyini belirlemek amacıyla geliştirilmiş olan ölçek toplamda 40 soru ve Durumluk Kaygı Envanteri (ilk 20 soru) ve Sürekli Kaygı Envanteri (son 20 soru) olmak üzere iki bileşenden oluşan dörtlü likert tiptedir. Durumluk kaygı ölçeği, bireyin belli bir zamanda ve belirli koşullar altında kendini nasıl hissettiğini, süreklilik kaygı ölçeği ise bireyin içinde bulunmuş olduğu durum ve koşullardan bağımsız olarak kendini nasıl hissettiğini belirlemektedir.

Durumluk ve Süreklilik Kaygı Envanteri’ndeki ölçekler, doğrudan ve tersine çevrilmiş türden ifadeler içermektedir. Doğrudan ifadeler, olumsuz duyguları belirtirken; tersine çevrilmiş ifadeler olumlu duyguları belirtmektedir. Durumluk Kaygı Envanteri'nde on $(1,2,5,8,10,11,15,16,19$. ve 20. maddeler) ve Süreklilik Kayg1 Envanteri'nde ise yedi (21, 26, 27, 30, 33, 36. ve 39. maddeler) tersine çevrilmiş madde vardır $(12,13)$. Envanterlerden elde edilen puanının 0-19 arasında olması bireyin kaygısının olmadığını, 20-39 arası puanın hafif kaygı düzeyine sahip olduğunu, 40-45 arası puanın orta düzeyde kaygıya sahip olduğunu, 60-79 arası puanın ise ağır kaygı düzeyine sahip olduğunu göstermektedir. Ayrıca 60 ve üzeri puan alan bireylerin profesyonel bir yardıma gereksinim olduğunu ifade etmektedir. Ölçeğin Öner tarafından yapılan geçerlik ve güvenirlik çalışmasında iç tutarlılık ve homojenlik kat sayısı, Durumluluk Kaygı Envanteri için .94 ve .96, Süreklilik Kaygı Envanteri için .83 ile .87 olarak belirlenmiş (12,13), bu araştırmada ise, Durumluluk Kaygı Envanteri Cronbach alfa değeri .93, Süreklilik Kaygı Envanteri Cronbach alfa değeri .86 olarak bulunmuştur.

\section{Verilerin Toplanmast}

Araştırmada verileri toplamak amacıyla online olarak hazırlanmış olan veri toplama formu, öğrencilere mail olarak iletilmiş ve öğrencilerden de bu veri toplama formunu farklı üniversitelerde hemşirelik bölümünde öğrenim görmekte olan arkadaşlarına iletmeleri konusunda destek istenmiştir.

\section{Verilerin Değerlendirilmesi}

Araştırmada elde edilen bulguların değerlendirilmesinde, istatistiksel analizler için IBM SPSS Statistics 20 (IBM SPSS, Türkiye) programı kullanılmıştır. Değişkenlerin normal dağılıma uygunluğu Kolmogrow Smirnov testi ile değerlendirilmiştir. Araştırma verileri değerlendirilirken tanımlayıcı istatistiksel metotların (ortalama, standart sapma, frekans) yanı sıra normal dağılım gösteren iki grup arası niceliksel verilerin değerlendirilmesinde normal dağılım gösteren verilerde Student t-Testi, normal dağılım göstermeyenlerde Mann Whitney U Testi, niceliksel verilerin ikiden fazla grup arası değerlendirmelerinde normal dağılım gösterenlerde Tek Yönlü ANOVA Testi ve farklılığa neden olan grubun belirlenmesinde Tukey HSD testi, normal dağılım göstermeyenlerde Kruskal Wallis Testi kullanılmıştır. Parametreler arası ilişkilerin değerlendirilmesinde Spearman Korelasyon Analizi kullanılırken, anlamlılık $p<0.05$ düzeyinde değerlendirilmiştir.

\section{Araştırmanın Etik Yönü}

Araştırmaya başlamadan önce araştırmada kullanılan ölçeklerin Türkçe geçerlik güvenirliğini yapmış olan yazarlardan e-mail aracılığıyla ölçek kullanım izni, Sağlık Bakanlığı Covid-19 Konusunda Bilimsel Araştırma Çalışmaları Komisyonu’ndan araştırmanın yapılabilmesine dair gerekli izin (2020-05-05T09_44_49), sonrasında bir üniversitenin klinik araştırmalar etik kurulundan etik kurul onayı (30.04.2020 tarihli, 2020/75 sayılı) alınmı_ştır. Hazırlanan online veri toplama formunun ilk sayfasına öğrenciler için bilgilendirilmiş onam kısmı eklenip, araştırmaya katılmak isteyen öğrenci tarafından onay verilmesi sağlandıktan sonra veri toplama formuna devam edebilmesi sağlanmıştır. Bu araştırma Helsinki Bildirgesi ilkelerine uygun olarak gerçekleştirilmiştir.

\section{Bulgular}

Araştırmaya katılan öğrencilerin yaş ortalamasının $20.27 \pm 1.66$ y1l, \%81.10’inin kadın, \%95.80’inin herhangi bir işte çalışmadığı, \%64.10'inin gelirinin giderine eşit olduğu, \%91.10'inin herhangi bir kronik hastalığının olmadığı, \%87.80'inin sigara içmediği ve genel not ortalamalarının $3.34 \pm 0.57$ puan olduğu saptanmıştır (Tablo 1). 
Tablo 1. Hemşirelik Öğrencilerinin Sosyo-Demografik Ö̈ellikleri $(n=810)$

\begin{tabular}{|c|c|c|}
\hline & Min-Maks & Ort \pm SS (Medyan) \\
\hline Yaş (yıl) & $18-39$ & $20.27 \pm 1.66(20.00)$ \\
\hline \multirow[t]{2}{*}{ Not ortalaması } & $1-4$ & $3.34 \pm 0.57(3.00)$ \\
\hline & n & $\%$ \\
\hline \multicolumn{3}{|l|}{ Cinsiyet } \\
\hline Kadın & 660 & 81.10 \\
\hline Erkek & 150 & 18.40 \\
\hline \multicolumn{3}{|l|}{ Sinıf } \\
\hline 1. Sinif & 337 & 41.40 \\
\hline 2. Sinıf & 223 & 27.40 \\
\hline 3. Sinıf & 140 & 17.20 \\
\hline 4. Sinıf & 110 & 13.50 \\
\hline \multicolumn{3}{|l|}{ Calışma durumu } \\
\hline Evet & 34 & 4.20 \\
\hline Hayır & 776 & 95.80 \\
\hline \multicolumn{3}{|l|}{ Gelir düzeyi } \\
\hline Gelir giderden az & 235 & 29.0 \\
\hline Gelir gidere eşit & 519 & 64.10 \\
\hline Gelir giderden fazla & 56 & 6.90 \\
\hline \multicolumn{3}{|c|}{ Kronik hastalık varlığı } \\
\hline Evet & 72 & 8.90 \\
\hline Hayır & 738 & 91.10 \\
\hline \multicolumn{3}{|l|}{ Sigara içme durumu } \\
\hline Evet & 99 & 12.20 \\
\hline Hayır & 711 & 87.80 \\
\hline
\end{tabular}

Öğrencilerin Uzaktan Eğitime Yönelik Görüşler Ölçeği’ nden en düşük 18, en yüksek 77 puan aldıkları ve ölçek toplam puan ortalamasının $46.35 \pm 9.13$, Durumluluk Kaygı Envanterin'nde en düşük 20, en yüksek 79 puan aldıkları ve ortalamasının 47.66 \pm 11.91 puan olduğu, Süreklilik Kaygı Envanteri’nden en düşük 25, en yüksek 79 puan aldıkları ve ortalamasının $46.39 \pm 8.42$ puan olduğu saptanmıştır (Tablo 2).

Tablo 2. Hemşirelik Öğgrencilerinin Uzaktan Eğitime Yönelik Görüşler Ölçeği (UEYGÖ) ve Durumluluk - Süreklilik Kaygı Envanteri Puanlarının Dağılımı

\begin{tabular}{llll}
\hline Ölçekler & Min-Maks & Ort \pm SS (Medyan) & $\begin{array}{l}\text { Cronbcah Alfa } \\
\text { Tutarlılık Katsayısı }\end{array}$ \\
\hline UEYGÖ & $18-77$ & $46.35 \pm 9.13(45)$ & .75 \\
Durumluluk Kayg1 & $20-79$ & $47.66 \pm 11.91(47)$ & .93 \\
Süreklilik Kaygı & $25-79$ & $46.39 \pm 8.42(46)$ & .86 \\
\hline
\end{tabular}

Öğrencilerin uzaktan eğitime yönelik görüşleri ile durumluluk kaygı düzeyleri arasında negatif yönde istatistiksel olarak ileri düzeyde anlamlı ilişki olduğu $(r=-.22, p=.001)$, uzaktan eğitime yönelik görüşleri ile süreklilik kaygı düzeyleri arasında ise negatif yönde istatistiksel olarak anlamlı bir ilişki olmadığg $(r=-.02, p=.525)$ saptanmıştır (Tablo 3).

Tablo 3. Uzaktan Eğitime Yönelik Görüşler Ölçeği ile Durumluluk-Süreklilik Kaygı Envanteri Puanları Arasındaki İlişki

\begin{tabular}{lll}
\hline & & Uzaktan Ĕ̆itime Yönelik Görüşler Ölçeği \\
\hline Durumluluk Kayg1 & $r$ & $-.22 * *$ \\
Süreklilik Kayg1 & $p$ & .000 \\
& $r$ & -.02 \\
& $p$ & .524 \\
\hline
\end{tabular}

$* p<0.05$

$r$ : Pearson Korelasyon Analizi 
Araştırma

Öğrencilerin Uzaktan Eğitime Yönelik Görüşler Ölçeği puan ortalamasının sınıf düzeyine göre farklılık gösterdiği ( $p=.004)$, birinci sınıfta öğrenim gören öğrencilerin UEYGÖ puan ortalamasının $45.61 \pm 8.45$, ikinci sınıfta öğrenim gören öğrencilerin puan ortalamasının $45.67 \pm 9.31$, üçüncü sınıfta öğrenim gören öğrencilerin puan ortalamasının $48.72 \pm 9.32$ ve dördüncü sınıfta öğrenim gören öğrencilerin puan ortalamasının $46.95 \pm 10.06$ puan olduğu, en düşük puan ortalamasının birinci sınıfta öğrenim görmekte olan öğrencilerde, en yüksek puan ortalamasının üçüncü sınıfta öğrenim görmekte olan öğrencilerde olduğu ve bu iki grup puan ortalaması arasında istatistiksel olarak anlamlı farklılık olduğu saptanmıştır. Öğrencilerin cinsiyet, çalışma durumu, gelir düzeyi, kronik hastalık düzeyi, sigara içme durumlarına göre UEYGÖ puan ortalamaları açısından istatistiksel olarak anlamlı farklılık olmadığ 1 belirlenmiştir (Tablo 4).

Öğrencilerin durumluluk kaygı envanteri puan ortalamasının gelir düzeyine göre farklılık gösterdiği $(p=.003)$, gelir düzeyi giderine eşit olanların, gelir düzeyi giderinden az olanlara göre daha az kaygı yaşadıkları, süreklilik kaygı envanterinde ise üç grup arasında istatistiksel olarak anlamlı farklılık olduğu $(p=.001)$, gelir düzeyi giderinden az olanların kaygı düzeyi puan ortalamasının diğer iki gruptan daha yüksek olduğu belirlenmiştir (Tablo 4).

Tablo 4. Genel Özelliklere Göre Uzaktan Ĕ̆itime Yönelik Görüşler Ölçeği ve Durumluluk-Süreklilik Kaygı Envanteri Puanlarının Değerlendirilmesi

\begin{tabular}{|c|c|c|c|c|c|c|c|c|}
\hline & & $\mathbf{n}$ & $\begin{array}{l}\text { UEYGÖ } \\
\text { Ort } \pm \text { SS }\end{array}$ & $\begin{array}{c}t / F \\
p\end{array}$ & $\begin{array}{c}\text { DKE } \\
\text { Ort } \pm \text { SS }\end{array}$ & $\begin{array}{c}t / F \\
p\end{array}$ & $\begin{array}{l}\text { SKE } \\
\text { Min- } \\
\text { Max. } \\
\text { (SD) }\end{array}$ & $\begin{array}{c}U / K W \\
p\end{array}$ \\
\hline Cinsiyet & $\begin{array}{l}\text { Kadın } \\
\text { Erkek }\end{array}$ & 660 & $\begin{array}{l}46.31 \pm 8.89 \\
46.48 \pm 10.15\end{array}$ & $\begin{array}{c}t=-0.202 \\
.067\end{array}$ & $\begin{array}{l}48.8 \pm 11.74 \\
45.79 \pm 12.48\end{array}$ & $\begin{array}{c}t=2.132 \\
.328\end{array}$ & $\begin{array}{c}27-73 \\
(46) \\
27-79 \\
(44) \\
\end{array}$ & $\begin{array}{c}U=41.251 \\
.001 *\end{array}$ \\
\hline Sinıf & $\begin{array}{l}\text { 1. Sinif } \\
\text { 2. Sinif } \\
\text { 3. Sinif } \\
\text { 4. Sinıf }\end{array}$ & $\begin{array}{l}140 \\
110\end{array}$ & $\begin{array}{l}45.61 \pm 8.45^{*} \\
45.67 \pm 9.31 \\
48.72 \pm 9.32^{*}\end{array}$ & $\begin{array}{c}F=4.496 \\
.004 *\end{array}$ & $\begin{array}{l}47.35 \pm 12.27 \\
48.32 \pm 12.01 \\
46.33 \pm 11.46 \\
48.95 \pm 11.07\end{array}$ & $\begin{array}{l}F= \\
1.320 \\
.267\end{array}$ & $\begin{array}{c}25-73 \\
(45) \\
26-79 \\
(47) \\
29-67 \\
(45) \\
25-69 \\
(47) \\
\end{array}$ & $\begin{array}{c}K W=2.807 \\
.422\end{array}$ \\
\hline $\begin{array}{l}\text { Çalışma } \\
\text { durumu }\end{array}$ & $\begin{array}{l}\text { Evet } \\
\text { Hayır }\end{array}$ & $\begin{array}{l}34 \\
776\end{array}$ & $\begin{array}{l}44.00 \pm 8.14 \\
46.45 \pm 9.16\end{array}$ & $\begin{array}{c}t=-1.534 \\
.057\end{array}$ & $\begin{array}{l}50.29 \pm 10.73 \\
47.46 \pm 11.95\end{array}$ & $\begin{array}{c}t=1.317 \\
.346\end{array}$ & $\begin{array}{c}33-62 \\
(48) \\
25-79 \\
(46) \\
\end{array}$ & $\begin{array}{c}U=11.725 \\
.272\end{array}$ \\
\hline $\begin{array}{l}\text { Gelir } \\
\text { düzeyi }\end{array}$ & $\begin{array}{l}\text { Gelir } \\
\text { giderden } \\
\text { az } \\
\text { Gelir } \\
\text { gidere } \\
\text { eşit } \\
\text { Gelir } \\
\text { giderden } \\
\text { fazla }\end{array}$ & 519 & $46.87 \pm 8.88$ & $\begin{array}{c}F=2.430 \\
.089\end{array}$ & $49.68 \pm 12.36^{*}$ & $\begin{array}{c}t=5.96 \\
.003^{*}\end{array}$ & $\begin{array}{c}31-79 \\
(48) * * * \\
\\
25-73 \\
(45)^{*} \\
29-69 \\
(44)^{* *}\end{array}$ & $\begin{array}{c}K W= \\
18.247 \\
.001 *\end{array}$ \\
\hline $\begin{array}{l}\text { Kronik } \\
\text { hastalık } \\
\text { varlığı }\end{array}$ & $\begin{array}{l}\text { Evet } \\
\text { Hayır }\end{array}$ & 72 & $\begin{array}{l}47.58 \pm 9.03 \\
46.23 \pm 9.14\end{array}$ & $\begin{array}{c}t=1.200 \\
.841\end{array}$ & $\begin{array}{l}52.25 \pm 11.96 \\
47.21 \pm 11.82\end{array}$ & $\begin{array}{c}t=3.446 \\
.907\end{array}$ & $\begin{array}{c}27-69 \\
(49) \\
25-79 \\
(46) \\
\end{array}$ & $\begin{array}{c}U=20.899 \\
.003 *\end{array}$ \\
\hline $\begin{array}{l}\text { Sigara } \\
\text { içme } \\
\text { durumu }\end{array}$ & $\begin{array}{l}\text { Evet } \\
\text { Hayır }\end{array}$ & $\begin{array}{l}99 \\
711\end{array}$ & $\begin{array}{l}44.98 \pm 9.46 \\
46.54 \pm 9.07\end{array}$ & $\begin{array}{c}t=-1.584 \\
.980\end{array}$ & $\begin{array}{l}50.79 \pm 13.36 \\
47.22 \pm 11.64\end{array}$ & $\begin{array}{c}t=2.529 \\
.045\end{array}$ & $\begin{array}{c}26-79 \\
(45) \\
25-73 \\
(46)\end{array}$ & $\begin{array}{c}U=36.898 \\
.782\end{array}$ \\
\hline
\end{tabular}

t: Bağımsız örneklem testi, $U$ : Mann Whitney U testi, $K W:$ Kruskal-Wallis testi, $F$ : Oneway Anova test istatistiği 


\section{Tartışma}

Dünyadaki birçok ülkede olduğu gibi ülkemizde de Covid-19 pandemi sürecinde bulaşı engellemek, sosyal mesafeyi sağlayabilmek için eğitim kurumlarında yüz yüze gerçekleştirilen örgün eğitime ara verilmiş ve bu nedenden dolayı tüm dünyada eğitim faaliyetleri olumsuz olarak etkilenmiştir. Eğitim faaliyetlerinin devam ettirilebilmesine yönelik ülkemizde de gerçekleştirilmiş olan uzaktan eğitim uygulamalarıyla eğitim faaliyetleri devam ettirilmeye çalışılmıştır. Bu süreçte eğitimlerine uzaktan devam etmek durumunda olan özellikle uygulamalı bölümlerde öğrenim gören öğrencilerin uzaktan eğitime yönelik diğer bölümde öğrenim görmekte olan öğrencilere göre daha fazla kaygı yaşayacakları düşünülerek bu araştırma, hemşirelik öğrencilerinin uzaktan eğitime yönelik görüşleri ile kaygı düzeyleri arasındaki ilişkiyi belirleyebilmek amacıyla planlanmıştır.

Araştırmada öğrencilerin Covid -19 pandemi sürecinde gerçekleştirilmiş olan uzaktan eğitime yönelik görüşlerinin orta düzeyde olduğu belirlenmiştir. Literatürde pandemi öncesi hemşirelik öğrencilerinin uzaktan eğitime yönelik görüşlerinin incelenmiş olduğu, Atasoy ve Sütütemiz'in (14) bir grup son sınıf hemşirelik öğrencisinin hemşirelik eğitimine ilişkin görüşlerini değerlendirdikleri araştırmada, öğrencilerin çoğunluğunun hemşirelik lisans derslerinin örgün eğitimle yürütülmesi gerektiğini ifade ettikleri, Süt ve Küçükkaya'nın (2) hemşirelik bölümü öğrencilerinin uzaktan eğitime ilişkin görüşlerini belirlemek amaciyla yapmış oldukları araştırmada öğrencilerin büyük çoğunluğunun uzaktan eğitime yönelik olumsuz düşünceye sahip olduğu saptanmıştır. Pandemi sürecinde hemşirelik öğrencilerinin uzaktan eğitime yönelik görüşlerini inceleyen Kürtüncü ve Kurt (15), Wang ve ark. (17) ve Sahu (18) yapmış oldukları araştırmalarda da benzer şekilde hemşirelik öğrencilerinin hem teorik derslerin hem de uygulamalı derslerin uzaktan eğitimle gerçekleştirilmesi konusunda olumsuz görüş bildirmiş oldukları belirlenmiştir. Literatürde araştırmanın bu bulgusunu destekleyen ve pandemi öncesi gerçekleştirilen araştırmalar olduğu gibi desteklemeyen araştırmalar da vardır. Şenyuva ve Taşocak (5), Şenyuva, Kaya ve Bodur (6) ve Taşocak ve ark. (19) öğrencilerin web tabanlı uzaktan eğitim uygulamasına yönelik öğrencilerin görüşlerini inceledikleri araştırmalarda, öğrencilerin web tabanlı eğitime yönelik olumlu görüşlere sahip olduğu belirtilmiştir. Araştırmanın bu bulgusu, Covid-19 pandemi öncesinde yapılan araştırma bulgularında da ortaya konmuş olduğu gibi hemşirelikte lisans eğitimi almakta olan öğrencilerin genel olarak uzaktan eğitime yönelik olumlu düşünceye sahip olmadıklarını sadece bazı teorik derslerin uzaktan eğitimle gerçekleştirilebileceğini ortaya koymaktadır.

Öğrencilerin Covid-19 pandemi sürecinde hissetmiş oldukları kaygı düzeyleri incelendiğinde, durumluluk ve süreklilik kaygı düzeylerinin orta düzeyde olduğu saptanmıştır. Benzer şekilde Covid -19 pandemi sürecinde öğrencilerin hissetmiş oldukları kaygı seviyelerini incelemek amaciyla Cao ve ark. (16), Wang ve ark. (17) tarafindan yapılan araştırmalarda da, öğrencilerin büyük çoğunluğunun Covid-19 nedeni ile kaygı hissettikleri belirlenmiştir. Taşocak ve ark. (19) tarafından pandemi öncesinde hemşirelik öğrencilerinin uzaktan eğitime ilişkin görüşleri ve kaygı düzeyleri arasındaki ilişkinin incelendiği araştırmada da araştırma bulgularına benzer şekilde öğrencilerin uzaktan eğitime ilişkin orta düzeyde kaygıya sahip oldukları belirlenmiştir. Konuyla ilgili literatürde özellikle üniversite öğrencilerine yönelik yapılmış olan araştırmaların sayısı oldukça sınırlı olmasına rağmen yapılmış olan araştırma bulgularının birbiri ile benzerlik gösterdiği, ülkemizdeki öğrencilerde olduğu gibi tüm dünyadaki öğrencilerin de kaygı hissetmiş oldukları saptanmıştır. Bu süreçte öğrencilerin eğitim süreçleri ile ilgili yaşamış oldukları belirsizlik durumlarının, tüm dünyada vaka sayılarında artış yaşanıyor olmasıyla ilişkili kendileri ve ailelerinin sağlık durumlarıyla ilgili hissetmiş oldukları kaygı durumlarını olumsuz yönde etkilemiş olabileceğini düşündürmüştür.

Öğrencilerin uzaktan eğitime ilişkin görüşleri ile durumluluk kaygı düzeyleri arasında negatif yönde istatistiksek olarak anlamlı bir ilişki, süreklilik kaygı düzeyleri ile istatistiksel olarak anlamlı bir ilişki olmadığı belirlenmiştir. Taşocak ve ark. (19) yapmış oldukları araştırmada öğrencilerin eğitim öncesi durumluluk kaygı düzeyleri ile uzaktan eğitime yönelik görüşleri arasında negatif yönde istatistiksel olarak anlamlı sonuç elde edilmişken, süreklilik kaygı düzeyleri ve eğitim sonrası durumluluk ve süreklilik kaygı düzeyleri arasında istatistiksel olarak anlamlı ilişki saptanmamıştır. Kürtüncü ve Kurt (15) hemşirelik öğrencileri ile yapmış oldukları araştırmada, Covid-19 pandemisi nedeniyle uzaktan eğitimle uygulamalı derslerin yapılamaması nedeniyle öğrencilerin çoğunluğunun yoğun kaygı yaşadıkları belirlenmiştir Literatürde oldukça sınırlı sayıda olan benzer araştırma bulgusu ile benzerlik gösteren araştırmanın bu bulgusu, hemşirelik alanında öğrenim gören öğrencilerin uygulamalı dersler nedeni ile uzaktan eğitimle uygulamaları yerine getirememe durumları nedeniyle kendilerini yetersiz hissetmelerinden dolayı durumluluk kaygı düzeylerinin artmış olabileceği şeklinde yorumlanmıştır.

Öğrencilerin sosyo - demografik özelliklerine göre uzaktan eğitime yönelik görüşleri incelendiğinde, cinsiyet, çalışma durumu, gelir düzeyi, kronik hastalık durumu ve sigara içme durumlarına göre uzaktan eğitime yönelik görüşleri arasında farklılık olmadığı fakat öğrencilerin sınıf durumuna göre uzaktan eğitime yönelik görüş ölçeği puanları arasında istatistiksel olarak farklılık olduğu saptanmıştır. Üçüncü sınıfta öğrenim gören öğrencilerin uzaktan eğitime yönelik görüş ölçeği puan ortalamasının diğer sınıflarda öğrenim gören öğrencilerden daha yüksek olduğu ve birinci sınıfta öğrenim gören öğrencilerle üçüncü sınıfta öğrenim gören öğrencilerin puan ortalamaları arasında istatistiksel olarak anlamlı bir fark olduğu belirlenmiştir. Araştırmanın bu bulgusu, birinci sınıfta öğrenim gören öğrencilerin hem teorik derslerde hem de uygulamalı derslerde yeterli bilgi birikimine sahip olmaması ve bir üst sınıfa geçtiklerinde kendilerini yeterli hissedemeyeceklerini düşünmüş olabilecekleriyle ilişkilendirilmiştir.

Öğrencilerin sosyo - demografik özelliklerine göre durumluluk ve süreklilik kaygı düzeyleri incelediğinde, cinsiyet, sınıf, çalışma durumu, kronik hastalık durumu ve sigara içme durumlarına göre kaygı düzeyleri arasında farklılık olmadığı belirlenirken, öğrencilerin gelir durumları ile durumluluk ve süreklilik kaygı düzeyleri arasında istatistiksel olarak anlamlı farklılık olduğu, geliri giderinden az olanların durumluluk kaygı düzeylerinin geliri giderine eşit olanlardan, geliri giderinden az olanların süreklilik kaygı düzeylerinin geliri giderine eşit ve geliri giderinden fazla olanlardan ve geliri giderine eşit olanların süreklilik kaygı düzeyinin de geliri giderinden fazla olanlardan yüksek olduğu belirlenmiştir. Cao ve ark. (16) yapmış olduğu araştırmada da araştırma bulgularına benzer şekilde öğrencilerin gelir durumunun kaygı düzeyini etkilediğini diğer değişkenlerin kaygı düzeyi üzerinde etkili olmadığını belirlemişlerdir. Araştırmada elde edilen bu bulgu, öğrencilerin Covid-19 sürecinde 
Araştırma

maddi olarak endişe hissettiklerini, diğer değişkenler açısından ise öğrencilerin benzer kaygı hissetmiş olabileceklerini düşündürmüştür.

\section{Kısıtlılıklar}

Araştırmada, pandemi dönemine ilişkin uzaktan eğitimi değerlendirmeye yönelik veri toplama aracının olmaması, verilerin genel geçerliliği olan uzaktan eğitime yönelik görüş ölçeği ile toplanması, sınırlı sayıda hemşirelik öğrencisine ulaşılmış olması ve tüm hemşirelik öğrencilerine genellenememesi, araştırmanın sınırlılıklarını oluşturmaktadır.

\section{Sonuçların Uygulamada Kullanımı}

Hemşirelik bölümü öğrencilerinin uzaktan eğitime yönelik orta düzeyde olumlu görüşe sahip oldukları, durumluluk ve süreklilik kaygı düzeylerinin orta düzeyde olduğu, uzaktan eğitime yönelik olumlu görüşleri arttıkça durumluluk kaygı düzeylerinin azalmış olduğu belirlenmiştir. Öğrencilerin uzaktan eğitime yönelik görüşlerinin sınıf düzeyine göre, durumluluk ve süreklilik kaygı düzeyinin gelir durumuna göre farklılık göstermiş olduğu saptanmıştır. Bu sonuçlar doğrultusunda, öğrencilerin uzaktan eğitime yönelik olumlu tutumlarının devam ettirilebilmesi ve kaygı düzeylerinin alt seviyede tutulabilmesi için otoriterelerin (Hemşirelik Eğitimi Derneği - HEMED vb.) önermiş olduğu çözüm önerilerinin göz önünde bulundurulması ve bilişsel, duyuşsal ve psikomotor becerilerin önemli olduğu bir bölüm olan hemşirelik bölümünde öğrenim görmekte olan öğrencilerin, bazı teorik derslerinin uzaktan eğitimle yapılabileceği fakat uygulamalı derslerin uygulama kısımlarının telafi eğitimleriyle tamamlanması gerektiği, uygulamalı derslerin uygulama kısımlarının telafi eğitimleriyle tamamlanması önerilebilir.

\section{Bilgilendirme}

Yazarlar araştırmaya katılan tüm hemşirelik öğrencilerine teşekkür etmektedir. Araştırmada yer alan yazarlar araştırmaya eşit oranda katkıda bulunmuşlardır. Yapılabilmesi için bir Üniversite Klinik Araştırmalar Etik Kurulu'ndan izin alınmıştır (30.04.2020 tarihli, 2020/75 sayılı). Araştırmada yazarlar arasında herhangi bir çıkar çatışması yoktur. Araştırma ile ilgili herhangi bir projeden ya da firmadan destek alınmamıştır.

\section{Kaynaklar}

1. Eygü H, Karaman S. Uzaktan eğitim öğrencilerinin memnuniyet algıları üzerine bir araştırma. KUSBD 2013; 3(1):36-59.

2. Öztürk D. Uzaktan eğitime hemşirelik eğitimi penceresinden bir bakış. Anadolu Hemşirelik ve Sağlık Bilimleri Dergisi 2015; 18(3):229-34.

3. Süt KH, Küçükkaya B. Hemşirelik bölümü öğrencilerinin uzaktan eğitime ilişkin görüşleri. HEAD 2016;13 (3): $235-243$.

4. United States Distance Learning Association (USDLA): Definition of distance learning. http://www.usdla.org/ 11 Haziran 2020.

5. Şenyuva E, Taşocak G. Implementation of web-based distance education in nursing education in turkey: a sample lesson in patient education. IJDET 2014; 12 (3): 1-13.

6. Şenyuva E, Kaya H, Bodur G. Hemşirelik öğrencilerinin web tabanlı bir derse ilişkin görüşleri. Ege Üniversitesi Hemşirelik Fakültesi Dergisi 2017; 33 (3): 62-77.

7. Bloomfield JG, While AE, Roberts JD. Using computer assisted learning for clinical skills education in nursing: 1ntegrative review. J Adv Nurs. 2008; 63(3): 222-235.

8. Şenyuva E. Hemşirelerin Uzaktan Eğitime İlişkin Görüşleri. ETKU 2013; 3(2):23-41.

9. Yüksek Öğretim Kurumu (YÖK). Uzaktan eğitime ilişkin alınan karar. https://covid19.yok.gov.tr/Documents/alinankararlar/03-uzaktan-egitime-iliskin-alinan-karar.pdf 08 Şubat 2021.

10. Yüksek Öğretim Kurumu (YÖK). Yüksek Öğretim Bilgi Yönetim Sistemi. https://istatistik.yok.gov.tr/ 26 Şubat 2021.

11. Yıldırım S, Yıldırım G, Çelik E, Karaman S. Uzaktan Eğitim öğrencilerinin uzaktan eğitime yönelik görüşleri: bir ölçek geliştirme çalışması. JRET 2014; 3(3): 2146-9199.

12. Öner N. Güvenirliği ve/veya geçerliği sınanmış psikolojik testler. Türk Psikoloji Dergisi 1994; 9(33): 9-18.

13. Öner N, Le Compte A. Durumluluk - Süreklilik Kaygı Envanteri Elkitabı. İstanbul: Boğaziçi Üniversitesi Matbaası; 1998: $1-26$.

14. Atasoy I, Sütütemiz N. Bir Grup hemşirelik son sınıf öğrencisinin hemşirelik eğitimi ile ilgili görüşleri. FNHD 2014; 22(2):94-104.

15. Kürtüncü M, Kurt A. Covıd-19 Pandemisi döneminde hemşirelik öğrencilerinin uzaktan eğitim konusunda yaşadıkları sorunlar. ASEAD 2020; 7 (5): 66-77.

16. Cao W, Fang Z, Hou G, Han M, Xu X, Dong J et al. The psychological 1mpact of the covid-19 epidemic on college students in china. Psychiatry Research 2020; 112934.

17. Wang C, Horby PW, Hayden FG, Gao GF. A novel coronavirus outbreak of global health concern. Lancet (2020); 395: 470473.

18. Sahu P. Closure of universities due to coronavirus disease 2019 (COVID-19): Impact on education and mental health of students and academic staff. Cureus (2020); 4: 4-9.

19. Tasocak G, Kaya H, Senyuva E, Işık B, Bodur, G. Relationship between nursing students' views about web-based patient education course and anxiety in Turkey. Turkish Online Journal of Distance Education (2014); 15(3): 197-214. 